\title{
Nesting ecology and population trend of leatherback turtles Dermochelys coriacea at Pacuare Nature Reserve, Costa Rica
}

\author{
Marga L. Rivas, Carlos Fernández and Adolfo Marco
}

\begin{abstract}
The leatherback turtle Dermochelys coriacea, the only extant species in its family, is categorized as Vulnerable on the IUCN Red List. The protection of nesting beaches and the associated conservation efforts along the Western Atlantic coast of Central America have improved the population trends of some of the most important rookeries. Here we report the life history, ecology and population trends of leatherback turtles over 18 years (1994-2012, excluding 1998) of effective protection in the Pacuare Nature Reserve, on the Caribbean coast of Costa Rica. A mean density of 142 nests per $\mathrm{km}$, probably the highest in Central America, indicates the importance of this rookery within the Caribbean region. Long-term conservation efforts at the Reserve have significantly reduced poaching and contributed to maintaining a high level of hatchling production. Long-term monitoring has also facilitated estimation of relevant demographic parameters of the population, such as nesting success (mean 69.8 \pm SD 7.3\%), clutch size (which is positively correlated with female size), hatching success (mean 55.2 \pm SD 6.0\%), remigration interval (2.5 years), and growth rate of remigrant females (mean $0.3 \pm \mathrm{SD} 1.0$ $\mathrm{cm}$ per year), which is slightly faster than growth rates reported for Pacific leatherback turtles. Overall, efforts at Pacuare have been successful in protecting leatherback turtles and understanding their life history, highlighting the importance of long-term conservation projects for maintaining threatened leatherback populations.
\end{abstract}

Keywords Caribbean, conservation, leatherback turtles, monitoring, protected areas, reproduction, threats

\section{Introduction}

$\mathrm{L}$ eatherback turtles Dermochelys coriacea were categorized as Critically Endangered on the IUCN Red List in 2000 on the basis that they faced 'an extremely high risk of extinction in the wild in the immediate future'

Marga L. Rivas* (Corresponding author) and Carlos Fernández Endangered Wildlife Trust, Avda. 11, San José, Costa Rica. E-mail mrivas@ugr.es

Adolfo Marco Department of Conservation of Biodiversity, Estación Biológica de Doñana, CSIC, Seville, Spain

${ }^{*}$ Also at: Department of Zoology, University of Granada, Campus Fuentenueva s/n, 18071 Granada, Spain

Received 3 April 2014. Revision requested 12 June 2014.

Accepted 29 August 2014. First published online 12 January 2015.
(Sarti-Martínez, 200o). This categorization has since been revised at the regional level because of varying population trends in the different ocean basins (Godfrey \& Godley, 2008; Seminoff \& Shanker, 2008; Wallace et al., 2013). An overview suggested the majority of populations in the Atlantic Ocean were stable or increasing, with some subpopulations, such as in the North-west Atlantic, categorized as Least Concern (Dutton et al., 2005; Turtle Expert Working Group, 2007; Girondot et al., 2007; Wallace et al., 2013). However, the Pacific populations were undergoing significant declines (Spotila et al., 2000; Reina et al., 2002; Seminoff et al., 2007). These differing trends make it necessary to analyse threats and population responses at the regional level. Wallace et al. (2010) defined Regional Management Units as a tool for identifying nesting areas and improving inter-regional understanding of marine turtle nesting distribution.

More information about turtle distribution and reliable estimates of demographic trends by capture-mark-recapture techniques are needed for a better analysis of the status and health of wild populations (Chaloupka \& Limpus, 2001). The size of leatherback turtles varies among populations (Stewart et al., 2007), and Atlantic Costa Rican leatherback turtles exhibit greater reproductive output than their eastern Pacific counterparts, with clutch sizes of $80-90$ eggs per clutch in the Atlantic and 60-65 eggs in the Pacific (Chacón, 1999; Reina et al., 2002; Hilterman \& Goverse, 2007; Quiñones et al., 2007). Growth rates of adult females after reaching sexual maturity are $>0.2 \mathrm{~cm}$ per year in Pacific leatherback turtles (Price et al., 2006). It is estimated this species reaches sexual maturity at 5-30 years (Zug \& Parham, 1996; Dutton et al., 2005; Jones, 2009) and captive animals mature at 7-16 years of age (Jones et al., 2011). Remigration intervals are shorter and more stable in the Atlantic (2-3 years) than in the Pacific (c. 3.7 years), possibly reflecting greater foraging success in the Atlantic (Reina et al., 2002; Dutton et al., 2005; Girondot et al., 2007; Bailey et al., 2012). The annual mortality rate of adult females is estimated to be c. $11 \%$ for the Atlantic population of St Croix (Dutton et al., 2005) and c. 22\% for the Costa Rican Pacific population (Santidrián Tomillo et al., 2007). Hatching success of leatherback turtles (c. 50\%) is low compared to other marine turtles (reviewed by Bell et al., 2004; Wallace et al., 2004) such as Atlantic green turtles Chelonia mydas (63.5-86.0\%) in Tortuguero (De Haro et al., 2008; Segura \& Cajade, 2010), hawksbill turtles Eretmochelys 
imbricata (78.6\%) in the West Indies (Ditmer \& Stapleton, 2012) or loggerhead turtles Caretta caretta $(73.4,55.7$ and 70-80\%, reported in South Carolina (Caldwell, 1959), Florida (Witherington, 1986), and Cape Verde (Abella et al., 2007), respectively).

The main threats to leatherback turtles include poaching, commercial and artisanal fisheries (Morreale et al., 1996; Eckert \& Sarti 1997; Alfaro-Shigueto et al., 2007; Seminoff et al., 2007; Santidrián Tomillo et al., 2008), and climate change (Saba et al., 2007; Reina et al., 2009; Santidrián Tomillo et al., 2012). However, population responses to threats may differ among ocean basins.

The Caribbean coast of Central America may host the fourth largest nesting population of leatherback turtles (Patiño-Martínez et al., 2008), after Gabon, French Guiana-Suriname and Trinidad \& Tobago (Turtle Expert Working Group, 2007). On the Caribbean coast of Costa Rica the most important leatherback rookeries, with long-term monitoring records, are at Tortuguero, Pacuare Nature Reserve and Gandoca beaches (Troëng et al., 2004; Chacón-Chaverri \& Eckert, 2007). However, no previous scientific studies have assessed the status of the nesting population at Pacuare Nature Reserve despite the long-term monitoring and conservation programme, established in 1994. Because of the nature of the study and the relatively high nesting levels in Caribbean Costa Rica the Reserve could be an important contributor to the regional assessments of the species in the Caribbean region.

We assessed the importance of Pacuare Nature Reserve as a nesting site for leatherback turtles in the Caribbean by analysing nesting abundance and trends over 18 years, describing some aspects of their nesting ecology, and identifying the main threats and proposing conservation priorities to increase the population.

\section{Study area}

We conducted the study at Pacuare Nature Reserve, $45 \mathrm{~km}$ south-east of Tortuguero on the Caribbean coast of Costa Rica (Fig. 1). The mouth of the Pacuare river is $1 \mathrm{~km}$ from the northern limit of the Reserve and the Mondonguillo lagoon is located at the southern end of the Reserve. The nesting beach is $5.7 \mathrm{~km}$ long. The beaches in this area are high-energy sandy beaches with medium steep slopes. A number of beach monitoring projects have been conducted along this coast (Fig. 1) but long-term monitoring programmes ( $>10$ years) have been carried out at only five of these sites: Pacuare Nature Reserve, Tortuguero National Park, Las Tortugas Research Station, Manzanillo-Gandoca National Wildlife Refuge and Cahuita National Park-Playa Negra (Table 1). There are ongoing monitoring projects at the first three sites.

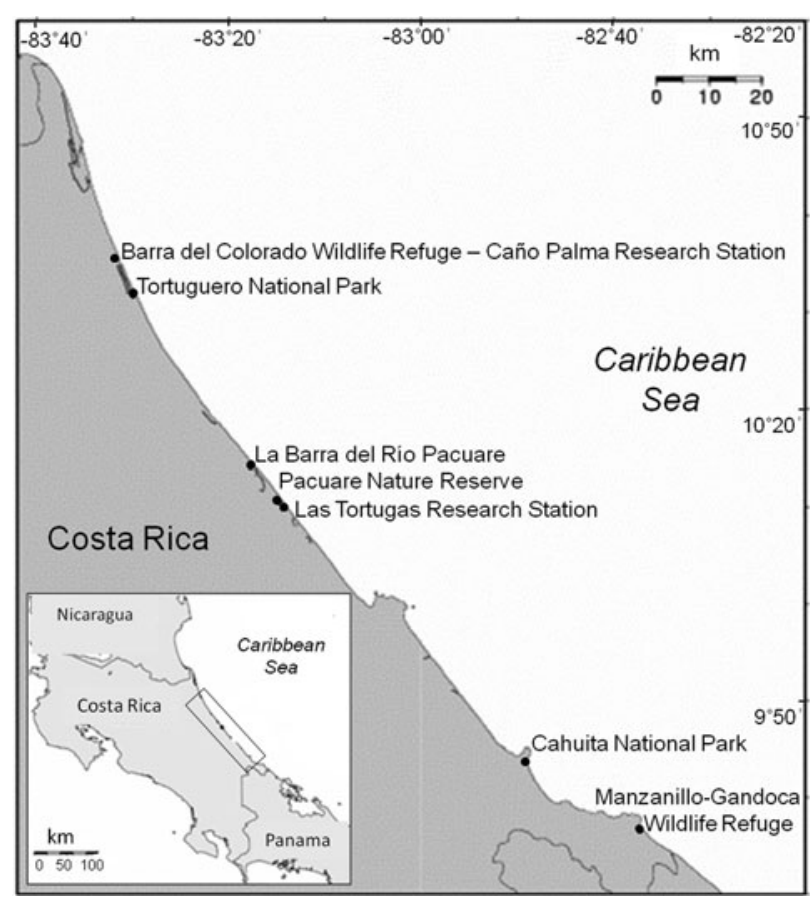

FIG. 1 Locations of marine turtle monitoring projects along the Caribbean coast of Costa Rica, Central America.

\section{Methods}

\section{Nesting surveys}

Two stations (north and south) were established at the borders of Pacuare Beach to monitor the total length of the beach. Along the coastline, we placed marker posts to divide the area into 100-m intervals, and marked sub-sectors every $25 \mathrm{~m}$ from the south (posts 0-57). Night patrols have been conducted during every nesting season (1 March-30 September) since 1994 (with the exception of 1998) along the total length of the beach, to monitor all nesting activities accurately and minimize egg poaching.

Each patrol team monitored the beach for 4 hours, starting from each station at 20.00, 22.00 and oo.00. Each turtle encountered was tagged and measured, and clutches found in risk-prone areas were relocated. Turtles were tagged with Monel 49 tags (National Band \& Tag Co., Newport, USA) on both rear flippers. Turtles that bore no evidence of tags, scars, holes or other deformities were considered new recruits to the rookery (Chacón, 1999; Troëng et al., 2004). Since 2001, subcutaneous microchip passive integrated transponder tags have been used (in $<5 \%$ of cases annually) in addition to flipper tags. Morning counts were conducted along the beach, to record every turtle track throughout the nesting season and to camouflage nests by flattening the sand to prevent egg poaching and predation by dogs. We estimated the number of nests per $\mathrm{km}$ to determine nest density by dividing the mean annual number of nests by the length of the beach. 
TABLE 1 Locations along the Caribbean coast of Costa Rica where marine turtle monitoring was carried out, with the year the projects commenced, the length of beach monitored, and the organizations leading the projects.

\begin{tabular}{llll}
\hline Marine turtle monitoring locations & Year & $\begin{array}{l}\text { Beach length } \\
(\mathrm{km})\end{array}$ & Organization \\
\hline $\begin{array}{l}\text { Barra del Colorado Wildlife Refuge-Caño Palma } \\
\text { Research Station }\end{array}$ & 2004 & 5 & $\begin{array}{l}\text { Canadian Organization for Tropical Education } \\
\text { and Rainforest Conservation }\end{array}$ \\
$\begin{array}{l}\text { Tortuguero National Park } \\
\text { La Barra del Río Pacuare }\end{array}$ & 1995 & 35.6 & $\begin{array}{l}\text { Sea Turtle Conservancy } \\
\text { Pacuare Nature Reserve }\end{array}$ \\
$\begin{array}{l}\text { Las Tortugas Research Station } \\
\text { Cahuita National Park-Playa Negra }\end{array}$ & 1994 & 5.7 & WIDECAST and La Tortuga Feliz \\
Manzanillo-Gandoca National Wildlife Refuge & 2000 & 3 & Endangered Wildlife Trust \\
& 2000 & 8.1 & Las Tortugas Research Station \\
\end{tabular}

\section{Biometry and nesting ecology}

We estimated mean nesting success as the proportion of nesting activities with oviposition relative to the abandoned attempts. We measured curved carapace length and width to the nearest mm, following Bolten (1999). Length was measured along the right side of the central ridge, and width across the widest part of the carapace from the outermost ridges. Before 2000 only the mean values of number of nests, curved carapace length and clutch size were available from annual technical reports (Rodríguez, 1994-1999). Biometric data and clutch size of a sample of remigrant females were also recorded and included in the annual reports. We calculated mean clutch size (number of eggs laid per successful nesting event) for this population over the years from 7,131 records. We recorded number of nests observed during female oviposition and without female presence since 2005 .

Since 2000 we have marked each nest with sticks and flagging tape, and measured the distances from nests to the north, south and middle sectorial posts. We monitored nests during incubation and emergence, and excavated them 2 days after hatching, or 75 days after eggs were laid. We calculated hatching success as the proportion of eggs that produced hatchlings: $H=S /(S+U)$, where $S=$ number of eggshells and $U=$ number of unhatched eggs. Eggshell fragments $\geq 50 \%$ of the egg surface were considered as one hatched egg (Miller, 1999). The total number of hatchlings at Pacuare Nature Reserve was calculated using the mean number of hatchlings estimated per clutch (hatching success multiplied by number of eggs in a clutch) multiplied by the total number of nests recorded. Research assistants were trained every season to use the same methodology.

A variable number of clutches were relocated each season to stable beach zones close to original sites if they were at risk of erosion and inundation and/or poaching.

\section{Remigrant females}

Tagged females or those with evidence of having been tagged previously (presence of holes, scars or skin deformations)

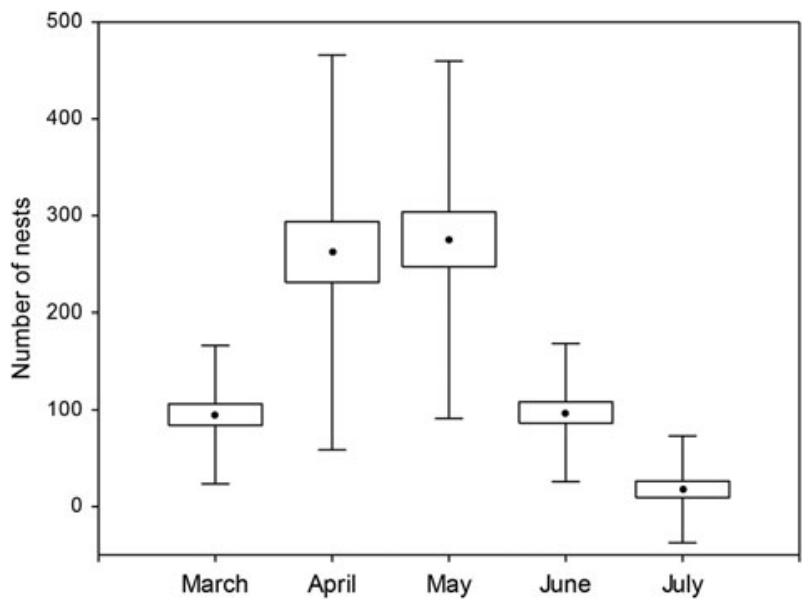

FIG. 2 Box plot of the number of clutches oviposited per month by female leatherback turtles Dermochelys coriacea during 1994-2012. The centre point in the box represents the mean value; the whiskers represent standard deviation.

were considered remigrants. We estimated growth rates and remigration intervals for a subsample of 330 females that were recaptured during a minimum of three nesting seasons over the study period, and used mean curved carapace length (based on at least two measurements) for each female encountered in each season. At the end of each season, errors $>_{1} \mathrm{~cm}$ among several annual measurements were removed before calculating mean error among observers.

We estimated observed and expected remigration intervals (number of years between consecutive nesting seasons) for every remigrant turtle. Observed intervals were calculated by dividing the number of years between the first and last oviposition by the number of seasons the turtle had nested. We calculated expected remigration intervals for a sample of 330 turtles by considering 2 years as a minimum remigration interval. We added one nesting event when inter-nesting intervals were $\geq 4$ years. To calculate the interannual variation in the number of clutches laid we calculated the coefficient of variation $(\mathrm{CV})$ from the mean and standard deviation (SD) of nests per female per 


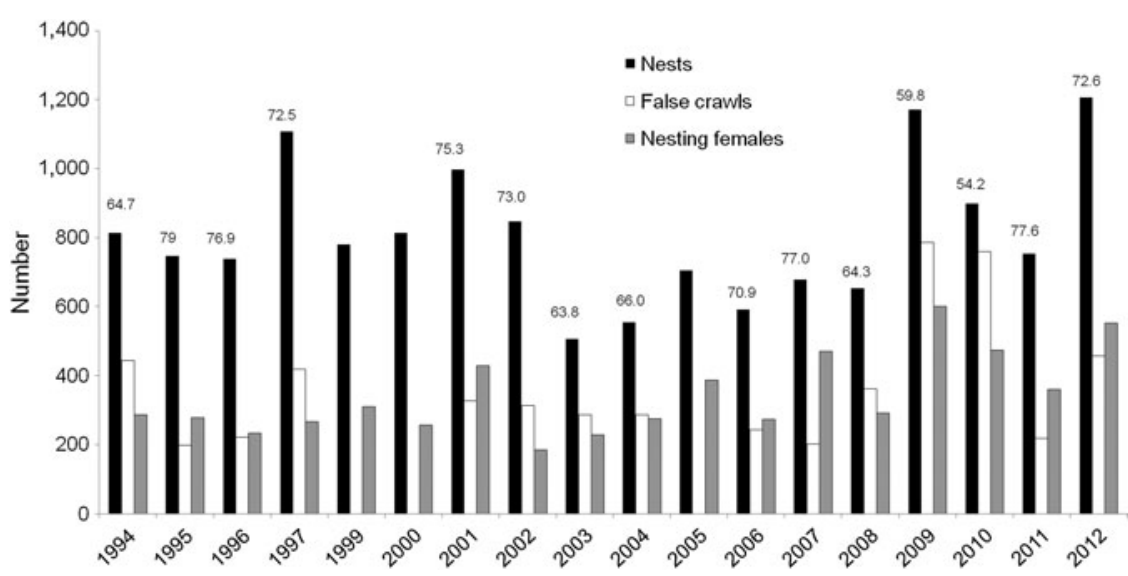

FIg. 3 Total number of clutches laid and false crawls (abandoned nesting attempts), and nesting females during 1994-2012 (excluding 1998). The numbers above the columns indicate nesting success (\%). year $(\mathrm{CV}=\mathrm{SD} /$ mean; Broderick et al., 2001). Finally, we analysed the variability in clutch size over time for 197 neophytes recorded at Pacuare, and for remigrants $(n=330)$ that laid nests in at least three seasons and twice in a year. We used mean clutch size when more than two ovipositions were recorded in a season. We analysed the correlation between curved carapace length and clutch size for this sample of remigrants.

We used XLSTAT.7.5.2 v. 2.o (Addinsoft, New York, USA) and STATISTICA v. 7.o (StatSoft, Inc., Tulsa, USA) to conduct all statistical analyses. Annual numbers of nesting females (remigrants and neophytes) and correlation between female size and clutch size were analysed using linear regression. Alpha was set at 0.05 . We used $\chi^{2}$ tests to compare annual fluctuations of nests, nesting success, female size, clutch size, and hatching success over seasons. We used ANOVA to determine clutch size variations between neophytes and remigrants, and observed vs expected remigration intervals.

\section{Results}

\section{Nesting population trends}

A total of 14,567 clutches were laid during the 18-year study. The highest nesting density occurred in April and May, followed by March and June (Fig. 2). February and August were excluded from the analysis because low numbers of nests were recorded during these months.

Overall, there was no significant change in nest numbers over the monitored period (linear regression, $r^{2}=0.015$, $F_{1,16}=0.24, \mathrm{P}=0.63, \mathrm{n}=18$; Fig. 3) but in 2012 the greatest number of nests ever $(n=1,206)$ was recorded at the Reserve.

We estimated a mean annual nesting density of 142.0 nests $\mathrm{km}^{-1}$ over the duration of the study, with the highest annual nesting density (211.6 nests $\mathrm{km}^{-1}$ ) occurring in 2012. In 2009 a total of 380 clutches $\left(126.6\right.$ nests $\mathrm{km}^{-1}$ ) were recorded in the northern sectors (0-29) and 789 clutches
(263 nests $\mathrm{km}^{-1}$ ) in the southern sectors (30-60), revealing a trend for higher nesting density in southern compared to northern sectors.

The annual mean number of nesting females was $342 \pm$ SD 118, of which $127 \pm$ SD 77 were neophytes (range 44-252) and 215 \pm SD 140 were remigrants (range 32-472; Table 2). Both the annual number of nesting females and the number of remigrant females increased slightly during the study (linear regression, $r^{2}=0.40, \quad F_{1,17}=10.75$, $\mathrm{P}=0.005, \mathrm{n}=18$, and $r^{2}=0.83, F_{1,17}=80.9, \mathrm{P}<0.001, \mathrm{n}=18$, respectively).

During the 18 years of the study 20,090 nesting activities (nests and false crawls) were recorded. Since 2005 a mean of $71.2 \pm$ SD $11.5 \%$ of all nests were recorded during female oviposition every season. The mean annual numbers of nests and abandoned nesting attempts were 809.3 \pm SD 201.6 (range 507-1,206) and 368.2 \pm SD 184.87 (range 198-786), respectively (Table 2 ). The difference between observed and expected numbers of nests for the hypothesis of non interannual variation was significant $\left(\chi^{2}=587.03, \mathrm{P}<0.0001\right)$, reflecting annual fluctuations. Mean nesting success at Pacuare was $69.8 \pm$ SD 7.3\% (range 54.2-79, $\mathrm{n}=15$; Table 2; Fig. 3). There were no significant differences in percentages of nesting success over the 18 years $\left(\chi^{2}=10.64, \mathrm{P}=0.71\right)$.

\section{Biometry and nesting ecology}

The annual mean curved carapace length was $152.3 \pm$ SD 1.28 $\mathrm{cm}(\mathrm{n}=17$ seasons). The smallest and largest turtles recorded in Pacuare Nature Reserve had curved carapace lengths of 138 and $178 \mathrm{~cm}$, respectively. The annual mean curved carapace width was $111.0 \pm$ SD $0.9 \mathrm{~cm}(\mathrm{n}=17$ seasons; Table 2). There was not a significant difference in female size among seasons $\left(\chi^{2}=16, P=0.45\right)$. The annual mean clutch size over 10 years was $77.7 \pm$ SD 2.1 eggs. We did not find significant differences in mean clutch size among years $\left(\chi^{2}=13, P=0.37\right)$.

Mean annual hatching success over the study period was $55.2 \pm$ SD 6.0\% (Table 2) from a total of 3,927 clutches 
TABLE 2 Summary of biological data recorded during 1994-2012: curved carapace length (CCL), curved carapace width (CCW), number of neophytes, number of remigrants, number of nests and false crawls, clutch size, hatching success and nesting success. Blank cells indicate no data.

\begin{tabular}{|c|c|c|c|c|c|c|c|c|}
\hline Year & $\mathrm{CCL}^{*}, \mathrm{~cm}(\mathrm{n})$ & $\mathrm{CCW}^{*}, \mathrm{~cm}$ & $\begin{array}{l}\text { No. of } \\
\text { neophytes }\end{array}$ & $\begin{array}{l}\text { No. of } \\
\text { remigrants }\end{array}$ & $\begin{array}{l}\text { No. of nests } \\
\text { (false crawls) }\end{array}$ & Clutch size ${ }^{*}$ & $\begin{array}{l}\text { Hatching success }{ }^{*} \text {, } \\
\%(\mathrm{n})\end{array}$ & $\begin{array}{l}\text { Nesting } \\
\text { success }^{\star}(\%)\end{array}$ \\
\hline 1994 & $154(203)$ & 111.4 & 252 & 34 & $814(443)$ & 76.8 & & 64.7 \\
\hline 1995 & $153.5(219)$ & 111.5 & 246 & 32 & 747 (198) & & & 79.0 \\
\hline 1996 & $154.1(201)$ & 111.3 & 188 & 45 & $738(222)$ & & & 76.9 \\
\hline 1997 & & & 198 & 69 & $1108(419)$ & & & 72.5 \\
\hline 1999 & $154.6(330)$ & 112.6 & 219 & 91 & 781 & & & \\
\hline 2000 & $152(370)$ & 110 & 90 & 167 & 814 & 74 & 62 & \\
\hline 2001 & $152(383)$ & 111 & 243 & 185 & $997(327)$ & 78 & $50(126)$ & 75.3 \\
\hline 2002 & $153(613)$ & 111 & 56 & 128 & $848(313)$ & 78 & $52(110)$ & 73.0 \\
\hline 2003 & $152(229)$ & 111 & 68 & 161 & 507 (287) & 78 & $58.3(120)$ & 63.8 \\
\hline 2004 & $151.9(238)$ & 110.9 & 49 & 226 & $555(286)$ & 77 & $58.2(206)$ & 66.0 \\
\hline 2005 & $153.8(570)$ & 111.7 & 44 & 343 & 706 & 81.6 & & \\
\hline 2006 & $151.2(515)$ & 110 & 61 & 213 & $591(243)$ & 75.2 & $42(490)$ & 70.9 \\
\hline 2007 & $150.8(157)$ & 109.3 & 110 & 361 & $678(202)$ & & & 77.0 \\
\hline 2008 & $152.1(425)$ & 110.8 & 57 & 235 & $653(362)$ & 76.8 & $62.1(354)$ & 64.3 \\
\hline 2009 & $151.2(801)$ & 110.2 & 149 & 451 & $1171(786)$ & 79.1 & $58.5(838)$ & 59.8 \\
\hline 2010 & $150.4(473)$ & 109.5 & 111 & 362 & $899(760)$ & 77 & $57.9(580)$ & 54.2 \\
\hline 2011 & $151.2(556)$ & 110.2 & 63 & 298 & $754(218)$ & 77.5 & $55.8(546)$ & 77.6 \\
\hline 2012 & $151.5(848)$ & 110.3 & 80 & 472 & $1206(457)$ & 81 & $50.4(557)$ & 72.6 \\
\hline$M e a n \pm S D$ & $152.3 \pm 1.28(7,131)$ & $111.0 \pm 0.86$ & $126.9 \pm 76.67$ & $215.2 \pm 140.17$ & $809.3 \pm 201.6(368.2 \pm 184.87)$ & $77.7 \pm 20.6(n=4,967)$ & $55.2 \pm 6.05(3,927)$ & $69.8 \pm 7.34$ \\
\hline
\end{tabular}

${ }^{*}$ Mean values for $1994-1999$ were obtained from technical reports. 
excavated, and a mean of $47.8 \pm$ SD $25.5 \%$ of nests (range 13-83) were excavated per season. The mean hatching success of nests did not change over time $\left(\chi^{2}=6.47, \mathrm{P}=0.77\right.$; Table 2). During 2009-2012 the mean hatching success was $59.4 \pm$ SD $25.8 \%$ (range o-100). We estimated a total of 618,943 hatchlings at the Reserve over the 18 -year study period.

\section{Remigrant females}

We estimated the annual growth rate of nesting females was $0.28 \pm$ SD $1.0 \mathrm{~cm}$ per year (range $0-3.1 ; \mathrm{n}=330$ ). The mean clutch size for the 330 females was 81.3 eggs, with a mean individual variation of 14.5 eggs per clutch (range 1-55) for all seasons; this mean clutch size was significantly greater than the mean of 74.3 eggs estimated for neophytes $(n=197$; ANOVA, $\left.F_{(329,196)}=1.95, \mathrm{P}<0.0001\right)$. There was a significant positive correlation between female size and clutch size (linear regression, $r^{2}=0.12, F=37.21, \mathrm{P}<0.05, \mathrm{n}=271$; Fig. 4). Approximately $49 \%$ of the females $(n=109)$ showed a variation in clutch size of $0-10$ eggs difference among clutches over the years, c. $25 \%$ laid clutches with a variation of 11-20 eggs, and $13.8 \%$ laid clutches with a variation of $21-$ 30 eggs. For $12 \%$ of females there were differences of $>30$ eggs between clutches laid in different nesting seasons.

Finally, the mean remigration interval observed at the Reserve was $2.5 \pm$ SD 1 .0 years (range $1-6, n=330$ turtles) and the mean expected remigration interval was $2.1 \pm$ SD o.6 years (range $1-9, n=330$ turtles). Remigration interval was not related to female size (ANOVA, $F=0.33, \mathrm{P}=0.56$ ). The interannual variation in the total number of observed clutches in any one season was low $(\mathrm{CV}=0.32)$.

\section{Discussion}

\section{Nesting trend}

The turtle monitoring project at Pacuare Nature Reserve is one of the three oldest established in Caribbean Costa Rica, after Gandoca-Manzanillo National Wildlife Refuge and Tortuguero National Park (Table 1). Despite conservation efforts along the coast there remain extended sections of unmonitored nesting beaches (Fig. 1), where nest poaching and turtle harvesting are common (authors, pers. obs.; Chacón, 1999; Troëng et al., 2004; Chacón-Chaverri \& Eckert, 2007).

Nesting density in the Reserve is the highest in Central America (142 nests $\mathrm{km}^{-1}$ ), exceeding the previous estimate of 91.6 nests $\mathrm{km}^{-1}$, based on aerial surveys (Troëng et al., 2004), and the density at Chiriqui beach (128 nests $\left.\mathrm{km}^{-1}\right)$, which was previously considered the most densely nested area (Ordoñez et al., 2007). The number of nesting turtles at the Reserve seems to be increasing, with a maximum recorded in 2012. Similar trends have been observed in other Atlantic rookeries, such as St Croix (Dutton et al., 2005),

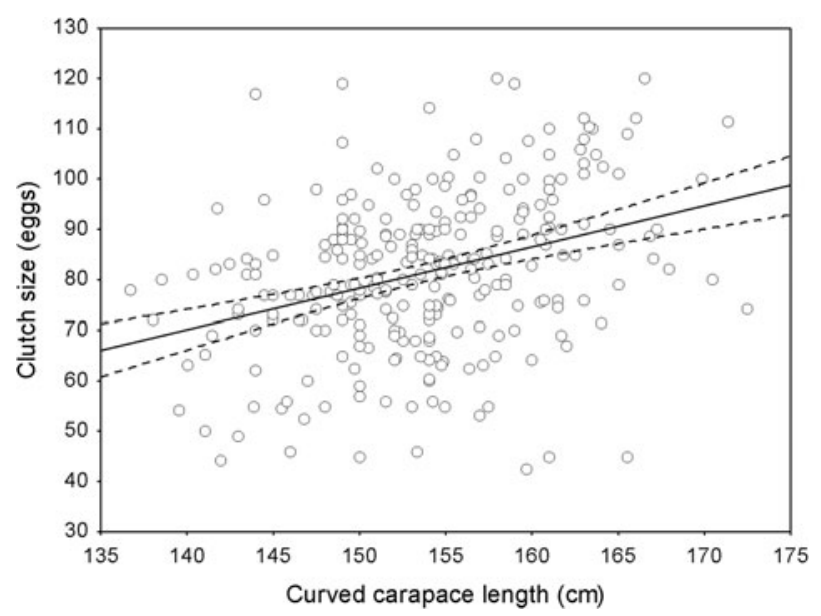

FIG. 4 Relationship between clutch size and female size (curved carapace length). The solid line corresponds to loess regression $(\mathrm{n}=330$ nesting females $)$ and the dashed lines indicate approximate pointwise $95 \%$ confidence intervals.

French Guiana and Suriname (Girondot et al., 2007), and Florida (Stewart et al., 2011), as well as for other marine turtle species in the area (Troëng \& Rankin, 2005; Antworth et al., 2006).

Long-term data are needed for correct interpretation of interannual variations in nesting numbers, imperfect counting of individuals, and the improvement in surveys over the years (Pfaller et al., 2013). Over the duration of the project a high number of neophytes were recruited to the population. The highest number $(n=243)$ was recorded in 2001, after which there was no further increase. Movement of female leatherback turtles between nesting beaches is common on the Caribbean coast of Costa Rica, and we have identified turtles tagged at other projects from northern Costa Rica (Caño Palma, Tortuguero; Fig. 1) to northern Panama (Chiriquí beach). A high level of exchange is also suggested by the low nest fidelity at Pacuare (mean 2-3 nests per season) compared to that of other populations (mean c. 7 nests; Reina et al., 2002).

\section{Biometry and nesting ecology}

Turtle sizes were similar to those reported at other nesting sites in the region (reviewed by Thomé et al., 2007). Mean clutch size was similar to those reported for Gandoca and other nesting populations in the Caribbean (Chacón, 1999; Chacón-Chaverri \& Eckert, 2007; Ordoñez et al., 2007) but was slightly lower than in Tortuguero (Leslie et al., 1996). Almost half of the females showed low variability in clutch size among years (range o-10 eggs among clutches). Mean hatching success $(55.2 \%)$ was higher than that reported for Tortuguero (41.5-46.5\%; Troëng et al., 2007) and did not vary significantly among years.

We found a positive correlation between mean curved carapace length and clutch size of remigrant females, similar 
to other marine turtle species (Hirth, 1980) but unlike other leatherback turtle populations (Hirth et al., 1993; Reina et al., 2002). We estimated the mean growth rate of nesting females was $0.28 \pm S D 1.0 \mathrm{~cm}$ per year, faster than that reported by Price et al. (2006) for Pacific leatherback turtles. At a growth rate of $0.28 \mathrm{~cm}$ per year it would take 143 years for a turtle measuring $138 \mathrm{~cm}$ (the smallest nester) to grow to $178 \mathrm{~cm}$ (the largest nester). Thus, it seems a reasonable assumption that the variation in female size is caused by size variability at the time they reach maturity, rather than growth after the time of first reproduction.

Observed remigration intervals at Pacuare Nature Reserve were 2.5 years, similar to those recorded by Dutton et al. (2005) in St Croix. Interannual variation in nesting numbers was lower than that recorded in French Guiana, and probably reflects consistent foraging conditions for leatherback turtles in the Atlantic across years (Broderick et al., 2001).

\section{Threats and conservation implications}

Marine turtles face persistent threats from fishery by-catch (Alfaro-Shigueto et al., 2007; Georges et al., 2007), egg poaching (Troëng et al., 2004, 2007; Ordoñez et al., 2007) and tourism (Katselidis et al., 2013). Intensive beach patrolling and the presence of guards reduced poaching of eggs at Pacuare compared to poaching levels before the project was established. The lowest number of nests was recorded in 2003 and nesting levels remained low until 2009, possibly as a result of the high levels of egg poaching that occurred at the site prior to the early 1990s. Although poaching was reduced to c. $1-2 \%$ per year after protection started, c. $10 \%$ of clutches were still poached in 2008 .

Conservation programmes in protected areas can facilitate recovery of marine turtle populations (Revuelta et al., 2012). Nesting population levels at Pacuare Nature Reserve indicate that long-term beach protection may be an effective conservation mechanism, reducing poaching and increasing beach productivity. However, declining trends were reported for Gandoca and Tortuguero in 2004 and 2006, respectively (Chacón-Chaverri \& Eckert, 2007; Troëng et al., 2007), and it is possible that turtles shifted from those locations to Pacuare, given the low site fidelity exhibited in this area. To assess population trends and status for the Caribbean Regional Management Unit as a whole, it is necessary to collate information from various research projects. Conservation programmes will continue at Pacuare Nature Reserve and a complete regional analysis will be the future research challenge.

\section{Acknowledgements}

We thank the Endangered Wildlife Trust Directors John Denham and Carlos Fernandez for their management of
Pacuare Nature Reserve and their support for conservation projects. We also thank the coordinators and assistants at Pacuare Nature Reserve, without whom this project would not have been possible: Stanley Rodríguez, Belinda Dick, Rubén Venegas, David Melero, Scott Handy, Sara Lucas, Isabel Rose and Francisco Ferrer. We thank Pilar Santidrián, David Booth, Graeme Hays and Connie Foss for their comments. Research permits were obtained from the Ministry of Environment and Energy (MINAE) of Costa Rica (R-SINAC-ACLAC-PIME-009-2013).

\section{References}

Abella, E., Marco, A. \& López-Jurado, L.F. (2007) Success of delayed translocation of loggerhead turtle nests. The Journal of Wildlife Management, 71, 2290-2296.

Alfaro-Shigueto, J., Dutton, P.H., Van Bressem, M.F. \& MANGEL, J. (2007) Interactions between leatherback turtles and Peruvian artisanal fisheries. Chelonian Conservation and Biology, 6, 129-134.

Antworth, R.L., Pike, D.A. \& Stiner, J.C. (2006) Nesting ecology, current status, and conservation of sea turtles on an uninhabited beach in Florida, USA. Biological Conservation, 130, 10-15.

Bailey, H., Fossette, S., Bograd, S.J., Shillinger, G.L., Swithenbank, A.M., Georges, J.-Y. et al. (2012) Movement patterns for a Critically Endangered species, the leatherback turtle (Dermochelys coriacea), linked to foraging success and population status. PLoS ONE, 7(5), e36401.

Bell, B.A., Spotila, J.R., Paladino, F.V. \& Reina, R.D. (2004) Low reproductive success of leatherback turtles, Dermochelys coriacea, is due to high embryonic mortality. Biological Conservation, 115, 131-138. Bolten, A.B., Eckert, K.L., Bjorndal, K.A., Albreu-Grobois, F. A. \& Donelly, M. (1999) Techniques for measuring sea turtles. In Research and Management Techniques for the Conservation of Sea Turtles (eds K.L. Eckert, K.A. Bjorndal, F.A. Abreu-Grobois \& M. Donnelly), pp. 110-114. IUCN/SSC Marine Turtle Specialist Group, Washington, DC, USA.

Broderick, A.C., Godley, B.J. \& Hays, G.C. (2001) Trophic status drives inter-annual variability in nesting numbers of marine turtles. Proceedings of the Royal Society of London B, 268, 1481-1487.

Caldwell, D.K. (1959) The loggerhead turtles of Cape Romain, South Carolina. Biological Science, 4, 319-348.

Chacón, D. (1999) Anidación de la Tortuga Dermochelys coriacea (Testudines: Dermochelyidae) en playa Gandoca, Costa Rica (1990-1997). Revista de Biología Tropical, 47, 225-236.

Chacón-Chaverri, D. \& Eckert, K.L. (2007) Leatherback sea turtle nesting at Gandoca Beach in Caribbean Costa Rica: management recommendations from fifteen years of conservation. Chelonian Conservation and Biology, 6, 101-110.

Chaloupka, M. \& Limpus, C. (2001) Trends in the abundance of sea turtles resident in southern Great Barrier Reef waters. Biological Conservation, 102, 235-249.

De Haro, A., Troeng, S. \& Harrison, E. (2008) How can monitoring of hatching success guide sea turtle management? In Proceedings of the 27th Annual Symposium on Sea Turtle Biology and Conservation (eds A.F. Rees, M. Frick, A. Panagopoulou \& K. Williams), pp. 88-89. NOAA/NMFS, Miami, USA.

Ditmer, M.A. \& Stapleton, S.P. (2012) Factors affecting hatch success of hawksbill sea turtles on Long Island, Antigua, West Indies. PLoS ONE, 7(7), e38472. 
Dutton, D.L., Dutton, P.H., Chaloupka, M. \& Boulon, R.H. (2005) Increase of a Caribbean leatherback turtle Dermochelys coriacea nesting population linked to long-term nest protection. Biological Conservation, 126, 186-194.

ECKERT, S.A. \& SARTI, L. (1997) Distant fisheries implicated in the loss of the world's largest leatherback nesting population. Marine Turtle Newsletter, 78, 2-7.

Georges, J.Y., Billes, A., Ferraroli, S., Fossette, S., Fretey, J., Gremillet, D. et al. (2007) Meta-analysis of movements in Atlantic leatherback turtles: conservation implications. Marine Ecology Progress Series, 388, 225-232.

Girondot, M., Godfrey, M.H., Ponge, L. \& Rivalan, P. (2007) Modeling approaches to quantify leatherback nesting trends in French Guiana and Suriname. Chelonian Conservation and Biology, 6, 37-46.

Godfrey, M.H. \& Godley, B.J. (2008) Seeing past the red: flawed IUCN global listings for sea turtles. Endangered Species Research, 6, 155-159.

Hilterman, M.L. \& Goverse, E. (2007) Nesting and nest success of the leatherback turtle (Dermochelys coriacea) in Suriname, 1999-2005. Chelonian Conservation and Biology, 6, 87-100.

Hirth, H.F. (1980) Some aspects of the nesting behavior and reproductive biology of sea turtles. American Zoologist, 20, 507-523.

Hirth, H.F., Kasu, J. \& MaLA, T. (1993) Observations on a leatherback turtle Dermochelys coriacea nesting population near Piguwa, Papua New Guinea. Biological Conservation, 65, 77-82.

Jones, T.T. (2009) Energetics of the leatherback sea turtle, Dermochelys coriacea. $\mathrm{PhD}$ thesis.. University of British Columbia, Vancouver, Canada.

Jones, T.T., Hastings, M.D., Bostrom, B.L., Pauly, D. \& Jones, D.R. (2011) Growth of captive leatherback turtles, Dermochelys coriacea with inferences on growth in the wild: implications for population decline and recovery. Journal of Experimental Marine Biology and Ecology, 399, 84-92.

Katselidis, K.A., Schofield, G., Stamou, G., Dimopoulos, P. \& PanTIS, J.D. (2013) Evidence-based management to regulate the impact of tourism at a key marine turtle rookery on Zakynthos Island, Greece. Oryx, 47, 584-594.

Leslie, A.J., Penick, D.N., Spotila, J.R. \& Paladino, F.V. (1996) Leatherback turtle, Dermochelys coriacea, nesting and nest success at Tortuguero, Costa Rica, in 1990-1991. Chelonian Conservation Biology, 2, 159-168.

Miller, J.D. (1999) Determining clutch size and hatching success. In Research and Management Techniques for the Conservation of Sea Turtles (eds K.L. Eckert, K.A. Bjorndal, F.A. Abreu-Grobois \& M. Donnelly), pp. 124-129. IUCN/SSC Marine Turtle Specialist Group, Washington, DC, USA.

Morreale, S.J., Standora, E.A., Spotila, J.R. \& Paladino, F.V (1996) Migration corridor for sea turtles. Nature, 384, 319-320.

Ordoñez, C., Troëng, S., Meylan, A., Meylan, P. \& Ruiz, A. (2007) Chiriqui Beach, Panama, the most important leatherback nesting beach in Central America. Chelonian Conservation and Biology, 6, 122-126.

Patiño-Martinez, J., Marco, A., Quiñones, L. \& Godley, B. (2008) Globally significant nesting of the leatherback turtle (Dermochelys coriacea) on the Caribbean coast of Colombia and Panama. Biological Conservation, 141, 1982-1988.

Pfaller, J.B., BJorndal, K.A., Chaloupka, M., Williams, K.L., Frick, M.G. \& Bolten, A.B. (2013) Accounting for imperfect detection is critical for inferring marine turtle nesting population trends. PLoS ONE, 8(4), e62326.

Price, E.R., Wallace, B.P., Reina, R.D., Spotila, J.R., Paladino, F.V., Piedra, R. \& Vélez, E. (2006) Size, growth, and reproductive output of adult female leatherback turtles Dermochelys coriacea. Endangered Species Research, 1, 41-48.
Quiñones, L., Patiño-Martinez, J. \& Marco, A. (2007) Factores que influyen en la puesta, la incubación y el éxito de eclosión de la tortuga laúd, Dermochelys coriacea, en La Playona, Chocó, Colombia. Revista Española Herpetología, 21, 5-17.

Reina, R.D., Mayor, P.A., Spotila, J.R., Piedra, R. \& Paladino, F.V. (2002) Nesting ecology of the leatherback turtle, Dermochelys coriacea, at Parque Nacional Marino Las Baulas, Costa Rica: 1988-1989 to 1999-200o. Copeia, 3, 653-664.

Reina, R.D., Spotila, J.R., Paladino, F.V. \& Dunham, A.E. (2009) Changed reproductive schedule of eastern Pacific leatherback turtles Dermochelys coriacea following the 1997-98 El Niño to La Niña transition. Endangered Species Research, 7, 155-161.

Revuelta, O., León, Y.M., Feliz, P., Godley, B.J., Raga, J.A. \& TomÁs, J. (2012) Protected areas host important remnants of marine turtle nesting stocks in the Dominican Republic. Oryx, 46, 348-358.

Rodriguez, S. (1994-1999) Reporte del proyecto de conservación de tortugas marinas, Reserva Pacuare, Costa Rica. Endangered Wildlife Trust, Costa Rica.

Saba, V.S., Santidrián Tomillo, P., Reina, R.D., Spotila, J.R., Musick, J.A., Evans, D.A. \& Paladino, F.V. (2007) The effect of the El Niño Southern Oscillation on the reproductive frequency of eastern Pacific leatherback turtles. Journal of Applied Ecology, 44, 395-404.

Santidrián Tomillo, P., Saba, V.S., Blanco, G.S., Stock, C.A., Paladino, F.V. \& Spotila, J.R. (2012) Climate-driven egg and hatchling mortality threatens survival of Eastern Pacific leatherback turtles. PLoS ONE, 7(5), e376o2.

Santidrián Tomillo, P., Saba, V.S., Piedra, R., Paladino, F.V. \& Spotila, J.R. (2008) Effects of illegal harvest of eggs on the population decline of leatherback turtles in Las Baulas Marine National Park, Costa Rica. Conservation Biology, 22, 1216-1224.

Santidrián Tomillo, P., Vélez, E., Reina, R.D., Piedra, R., Paladino, F.V. \& Spotila, J.R. (2007) Reassessment of the leatherback turtle (Dermochelys coriacea) nesting population at Parque Nacional Marino Las Baulas, Costa Rica: effects of conservation efforts. Chelonian Conservation and Biology, 6, 54-62.

Sarti-MartíneZ, A.L. (200o) Dermochelys coriacea. In IUCN Red List of Threatened Species v. 2011. Http://www.iucnredlist.org [accessed 15 October 2011].

SEgura, L.N. \& CAJADE, R. (2010) The effects of sand temperature on pre-emergent green sea turtle hatchlings. Herpetological Conservation and Biology, 5, 196-206.

Seminoff, J.A., Paladino, F.V. \& Rhodin, A.G.J. (2007) Refocusing on leatherbacks: conservation challenges and signs of success. Chelonian Conservation and Biology, 6, 1-6.

Seminoff, J.A. \& Shanker, K. (2008) Marine turtles and IUCN Red Listing: a review of the process, the pitfalls, and novel assessment approaches. Journal of Experimental Marine Biology and Ecology, $356,52-68$.

Spotila, J.R., Reina, R.D., Steyermark, A.C., Plotkin, P.T. \& Paladino, F.V. (2000) Pacific leatherback turtles face extinction. Nature, 405, 529-530.

Stewart, K., Johnson, C. \& Godfrey, M.H. (2007) The minimum size of leatherbacks at reproductive maturity, with a review of sizes for nesting females from the Indian, Atlantic and Pacific Ocean basins. Herpetological Journal, 17, 123-128.

Stewart, K., Sims, M., Meylan, A., Witherington, B., Brost, B. \& Crowder, L.B. (2011) Leatherback nests increasing significantly in Florida, USA; trends assessed over 30 years using multilevel modeling. Ecological Applications, 21, 263-273.

Thomé, J.C.A., Baptistotte, C., Moreira, L.M.P., Scalfoni, J.T., Almeida, A.P., Rieth, D.B. \& Barata, P.C.R. (2007) Nesting biology and conservation of the leatherback sea turtle (Dermochelys 
coriacea) in the state of Espírito Santo, Brazil, $1988-1989$ to 2003-2004. Chelonian Conservation and Biology, 6, 15-27.

Troëng, S., Chacón, D. \& Dick, B. (2004) Possible decline in leatherback turtle Dermochelys coriacea nesting along the coast of Caribbean Central America. Oryx, 38, 395-403.

Troëng, S., Harrison, E., Evans, D., de Haro, A. \& Vargas, E. (2007) Leatherback turtle nesting trends and threats at Tortuguero, Costa Rica. Chelonian Conservation and Biology, 6, $117-122$.

Trö̈ng, S. \& RANKIn, E. (2005) Long-term conservation efforts contribute to positive green turtle Chelonia mydas nesting trend at Tortuguero, Costa Rica. Biological Conservation, 121, $111-116$.

Turtle Expert Working Group (2007) An Assessment of the Leatherback Turtle Population in the Atlantic Ocean. NOAA Technical Memorandum NMFS- SEFSC-555. National Marine Fisheries Service, Miami, USA.

Wallace, B.P., DiMatteo, A.D., Hurley, B.J., Finkbeiner, E.M., Bolten, A.B., Chaloupka, M.Y. et al. (2010) Regional Management Units for marine turtles: a novel framework for prioritizing conservation and research across multiple scales. PLoS ONE, 5(12), e15465.

Wallace, B.P., Sotherland, P.R., Santidrián Tomillo, P.S., Bouchard, S.S., Reina, R.D., Spotila, J.R. \& Paladino, F.V. (2006) Egg components, egg size, and hatchling size in leatherback turtles. Comparative Biochemistry and Physiology. Part A: Molecular \& Integrative Physiology, 145, 524-532.
Wallace, B.P., Sotherland, P.R., Spotila, J.R., Reina, R.D., Franks, B.F. \& Paladino, P.V. (2004) Biotic and abiotic factors affect the nest environment of embryonic leatherback turtles, Dermochelys coriacea. Physiological and Biochemical Zoology, 77, $423-432$.

Wallace, B.P., Timari, M. \& Girondot, M. (2013) Dermochelys coriacea. In IUCN Red List of Threatened Species v. 2014.2. Http://www.iucnredlist.org [accessed 3 October 2014].

WiTHERINGTON, B.E. (1986). Human and natural causes of marine turtle clutch and hatchling mortality and their relationship to hatchling production on an important Florida nesting beach. MS thesis. University of Central Florida, Orlando, USA.

Zug, G.R. \& PARHAM, J.F. (1996) Age and growth in leatherback turtles, Dermochelys coriacea (Testudines: Dermochelyidae): a skeletochronological analysis. Chelonian Conservation and Biology, 2, 244-249.

\section{Biographical sketches}

MARGA Rivas has been studying marine turtles in the field for over 8 years and has studied the biology of nesting populations of leatherback, green, loggerhead and olive ridley turtles. CAR LOS FER NÁ N DEZ has directed the marine turtle monitoring project carried out at Pacuare Nature Reserve for the past 25 years. AD O L Fo MAR CO's research interests focus on marine turtle biology and ecology, and conservation of loggerhead and leatherback turtles. 